\title{
PEMODELAN VEKTOR METODE INTERIOR POINT UNTUK STUDI PEMBEBANAN MAKSIMUM SISTEM TENAGA LISTRIK
}

\author{
Yogi Jentrapolta Siregar ${ }^{1 *}$, Lukmanul Hakim², Osea Zebua ${ }^{3}$, Khairudin Hasan ${ }^{4}$ \\ 1,2,3,4 Jurusan Teknik Elektro, Universitas Lampung; Jl. Prof. Sumantri Brojonegoro No.1, Bandar \\ Lampung
}

Received: 17 November 2021

Accepted: 21 Desember 2021

Published: 10 Januari 2022

Keywords:

Python, Interior Point

Method. Loadability

Maksimum, dan Model

Vectorized

Corespondent Email:

yogi.j1129@students.unila.ac.id

\begin{abstract}
Abstrak. Beberapa tahun terakhir, pada sistem tenaga listrik beban yang ada semakin besar seiring peningkatan beban listrik. Permasalahan utama kondisi pembebanan akan menyebabkan ketidakstabilan tegangan di sistem tenaga listrik. Untuk mencegah ketidakstabilan sistem, penting bagi operator sistem tenaga untuk mengidentifikasi seberapa jauh sistem memuat dari kondisi kritisnya. Penelitian ini membahas masalah maksimum pembebanan dengan menggunakan metode non-linear primal-dual interior point method. Caranya dengan memaksimalkan beban sistem yang diwakili oleh pengganda skalar ke beban sistem. Kontribusi utama dari pekerjaan ini adalah dalam pengembangan model vectorized dari masalah dan pengembangan program aplikasi dalam bahasa pemrograman Pyhton. Model yang dikembangkan kemudian diuji untuk memecahkan masalah loadability maksimum untuk sistem pengujian IEEE 14-bus dan 30-bus. Simulasi dari model ini dan program komputer yang dikembangkan memberikan hasil yang memuaskan.
\end{abstract}

How to cite this article:

Yogi (2022). Pemodelan Vektor Metode Interior Point Untuk Studi Pembebanan Maksimum Sistem Tenaga Listrik. Jurnal Informatika dan Teknik Elektro Terapan, 10(1)

This article is an open-access article distributed under the terms and conditions of the Creative Commons Attribution (CC BY NC)

\begin{abstract}
In the recent years, electric power systems have become heavily loaded as electricity demand keeps increasing. This leads to critical loading condition which may cause voltage instability in the electric power systems. In order to prevent such systems from instability, it is of importance for power system operator to identify how far the system loading from its critical condition. This research addresses maximum loadability problem by means of non-linear programming primal-dual interior point method. This is achieved by maximizing system load represented by a scalar multiplier to system loads. Major contribution of this work is in the development of vectorized model of the problem and in-house development of application program in Pyhton programming language. The developed model was then tested to solve maximum loadability problem for IEEE 14-bus and 30-bus test systems. Simulations from this model and the developed computer program give satisfactory results.
\end{abstract}




\section{Pendahuluan}

Dari hari ke hari, kebutuhan akan energi listrik selalu meningkat, akibatnya beban yang semakin tinggi akan mempengaruhi kestabilan tegangan. Jika peningkatan beban terus terjadi, maka sistem akan collapse, dan akan terjadi ketidakseimbangan tegangan disistem. Ketidakseimbangan sistem akan mengakibatkan permasalahan disistem seperti, terjadinya penurunan tegangan disisi beban, kualitas daya yang rendah. Selain penurunan profil tegangan, pada pembebanan melebihi kapasitas maksimum akan meningkatkan nilai rugi-rugi daya yang dapat membahayakan jaringan sistem transmisi. Hal ini dapat mengurangi tingkat keamanan sistem tenaga listrik. Untuk dapat mencegah hal ini, maka operator sitem perlu melakukan identifikasi, sampai batas mana sistem dapat menopang kenaikan beban agar sistem tidak collapse saat terjadi peningkatan beban. Untuk itu perlu dilakukan studi lebih lanjut untuk dapat menyelesaikan permasalahan ini. Salah satu solusi untuk permasalahan kebutuhan beban adalah menganalisis kemampuan pembebenan maksimum (maximum loadability). Studi maximum loadabality menganalisis kemampuan sistem untuk dapat memikul beban yang terpasang hingga batas maksimum generator di sistem dapat menyuplai daya generator dengan memperhatikan batasan tegangan yang disetting.

Metode interior point yang digunakan penulis merupakan salah satu metode dalam perhitungan OPF. Dalam sejarah perkembangan dalam pembentukan metode ini, identifikasi masalah OPF dimulai pada awal tahun 1960-an oleh Carpentier yang membuat banyak penelitian mengenai alat dan perencanaan sistem tenaga. Tahun 1984 oleh D.I. Sun, dkk mengusulkan metode newton OPF untuk menyelesaikan permasalahan daya aktif dan reaktif. Namun metode ini masih mempunyai kendala dalam menyelesaikan permasalahan pertidaksamaan fungsi kendala. Tahun 1990-an, telah banyak metode yang digunakan untuk menyelesaikan permasalahan OPF, seperti Linear Programming, Quadratic Programming dan Nonlinear Programming. Namun permasalahan pada OPF semakin hari semakin banyak dan rumit sehingga terbuka lebar untuk menyelesaikan banyak permasalahan di OPF dengan metode yang digunakan. Pada tahun 1998 oleh H. Wei, dkk, dengan menggunakan metode interior point untuk kendala persamaan non-linear programming menyelesaikan dengan mereduksi 'matriks W' untuk mengeliminasikan variabel fungsi pertidaksamaan. Metode ini dapat menyelesaikan permasalahan OPF dengan skala besar. Tahun 2007, Yang Yude, dkk memperkenalkan metode interior point dengan pemodelan vektor. Dengan pemodelan vektor, Yang Yude memperkenalkan metode untuk membuat ulang setiap variabel yang ada dengan disusun kedalam matrix $\mathrm{n} \times \mathrm{n}$. Pada perhitungan secara konvensional perhitungan dilakukan per elemen variabel setelah itu dimasukkan kedalam elemen matrix, namun metode vektor melakukan pemodelan perhitungan secara matrix dari variabel yang telah disusun kedalam matrix tersebut.

Pada penelitian ini, penulis merepresentasikan permasalahan pembebanan maksimum dengan metode interior point sama seperti yang dilakukan oleh penelitian terdahulu, namun yang membedakan dengan penelitian menggunakan metode interior point lainnya adalah penulis menggunakan pemodelan vector untuk merepresentasikan matrix jaccobian dan matrix hessian ke dalam bentuk yang lebih sederhana dalam melakukan perhitungan dari penggunaan rumus aliran daya konvensional pada umumnya dengan python sebagai bahasa pemrograman yang digunakan.

\section{PEMBEBANAN MAKSIMUM PADA METODE INTERIOR POINT}

Dalam menyelesaikan permasalahan pembebenan maksimum, dilakukan pemodelan pembebanan kedalam bentuk $-\lambda$. Hal ini dilakukan untuk mendapatkan hasil maksimum dari fungsi objektif dari pembebanan. Nilai $\lambda$ ini digunakan sebagai pengali daya beban.

$$
\begin{array}{cc}
\text { Memperkecil } & f(x)=-\lambda \\
\text { Kendala Persamaan } & h(x)=0 \\
P_{G i}-(\lambda+1) P_{D i}-P_{i}(x)=0 \\
Q_{G i}-(\lambda+1) Q_{D i}-Q_{i}(x)=0
\end{array}
$$

Kendala Pertidaksamaan $\mathrm{g} \leq \mathrm{g}(\mathrm{x}) \leq \overline{\mathrm{g}}$

$$
\begin{aligned}
\underline{P_{G i}} & \leq P_{G i} \leq P_{G i} \\
\underline{Q_{G i}} & \leq Q_{G i} \leq \underline{Q_{G i}}
\end{aligned}
$$




$$
\begin{aligned}
& \frac{V_{i}{ }^{2}}{0 \leq \lambda} \leq V_{i} \leq \underline{V}_{i}^{2} \\
& S_{i j}{ }^{2} \leq S_{i j}{ }^{2} \leq S_{i j}{ }^{2} \\
& {S_{j i}{ }^{2}}^{2} \leq S_{j i}{ }^{2} \leq \underline{S_{j i}{ }^{2}}
\end{aligned}
$$

Dimana:

$P_{G i}, Q_{G i}=$ Vektor daya aktif dan daya reaktif generator

$S_{i j}, S_{j i}=$ Vektor aliran daya saluran

Karena pertidaksamaan kendala memiliki 2 bagian maka mempergunakan vektor variabel slack, $1, \mathrm{u} \in R^{r}$, persamaan diatas dapat diubah menjadi:

Memperkecil

Berdasarkan

$$
\begin{gathered}
f(x) \\
h(x)=0 \\
\mathrm{~g}(\mathrm{x})-\mathrm{g}-1=0 ; \\
\mathrm{g}(\mathrm{x})-\overline{\mathrm{g}}+\mathrm{u}=0 \\
(l, u) \geq 0
\end{gathered}
$$

Dengan menentukan fungsi Lagrangian yang terkait dengan persamaan diatas sebagai: $L(x, l, u, z, w, \underline{z}, \underline{w})=f(x)-y^{T} h(x)-$ $Z^{T}[g(x)-\mathrm{g}-l]-w^{T}[g(x)-\overline{\mathrm{g}}+u]-$ $\underline{z}^{T} l-\underline{w}^{T} u$

(16)

Dimana $y \in R^{m}$ dan $\mathrm{z}, \mathrm{w}, \underline{z}, \underline{w} \in R^{m}$ adalah lagrange multiplayer dan $\underline{z}=\mathrm{z}, \underline{w}=\mathrm{w}$

Berdasarkan kondisi optimal Karush-KuhnTucker (KKT), persamaannya sebagai berikut

$$
\begin{aligned}
L_{x}= & \nabla f(x)-\nabla h(x)-\nabla g(x)(z+w)=0 \\
L_{i}= & L Z e-\mu e=0 \\
L_{n}= & U W e+\mu e=0 \\
L_{y}= & h(x)=0 \\
L_{z}= & g(x)-g-l=0 \\
L_{w}= & g(x)-\underline{g}+u=0 \\
& (l, u) \geq 0, y \neq 0, z \geq 0 \& w \leq 0
\end{aligned}
$$

Dimana $\mathrm{L}, \mathrm{U}, \mathrm{Z}, \mathrm{W} \in R^{r x r}$ matriks diagonal dengan unsur $l_{i}, u_{i}, z_{i}$ dan $w_{i} . \mu>0$ adalah lagrange. $e=[1, \ldots, 1]^{T} \in R^{r}$.

Dengan menerapkan metode Newton ke KKT, penurunan persamaan koreksi dapat dinyatakan sebagai:

$\left[\sum_{i=1}^{m} \quad y i . \nabla^{2} \cdot h i(x)+\sum_{j=1}^{r} \quad\left(z_{j}+\right.\right.$ $\left.\left.W_{j}\right) \cdot \nabla^{2} g_{j}(x)-\nabla^{2} f(x)\right] \Delta x+\nabla h(x) \Delta y+$ $\nabla g(x)(\Delta z+\Delta w)=L_{x 0}(23)$

$Z \Delta l+L \Delta z=-L_{10}^{\mu}$

$$
\begin{aligned}
& W \Delta u+U \Delta w=-L_{u 0}^{\mu} \\
& \nabla h(x)^{T} \Delta x=-L_{y 0} \\
& \nabla g(x)^{T} \Delta x-\Delta l=-L_{x 0}
\end{aligned}
$$

$\nabla g(x)^{T} \Delta x-\Delta u=-L_{w 0}$

Persamaan ini diturunkan berkaitan dengan kondisi optimalitas Karush-Kuhn-Tucker (KKT). Rincian derivasi ini tersedia di persamaan sebelumnya. Dengan menerapkan metode Newton ke KKT, penurunan persamaan koreksi dapat dinyatakan sebagai:

$$
\begin{gathered}
{\left[H(\bullet) J(x)^{T} J(x) \quad 0 \quad\right][\Delta x \Delta y]=} \\
-[\psi(\bullet, \mu) \varnothing](29)
\end{gathered}
$$

Dimana:

$$
H(\bullet)=\left[\sum_{i=1}^{m} \quad y i . \nabla^{2} \cdot h i(x)+\sum_{j=1}^{r} \quad\left(z_{j}+\right.\right.
$$$$
\left.\left.W_{j}\right) \cdot \nabla^{2} g_{j}(x)-\nabla^{2} f(x)\right]+\nabla g(x) \operatorname{S} \nabla g(x)^{T}
$$

$$
\begin{aligned}
& J(x) \equiv \nabla h(x)^{T} \\
& \psi(\bullet, \mu) \equiv \nabla h(x) y-\nabla f(x)+ \\
& \nabla g(x)\left[U^{-1} W L_{W 0}-L^{-1} Z L_{z o}-\mu\left(U^{-1}-\right.\right. \\
& \left.\left.L^{-1}\right) e\right] \quad \emptyset \equiv h(x)
\end{aligned}
$$

Step Length untuk mencari fungsi Lagrange $\Delta \mathrm{l}=\nabla g(x)^{T} \Delta x+L_{z 0}$

$$
\text { (33) }
$$

$\Delta u=-\left(\nabla g(x)^{T} \Delta x+L_{w 0}\right)$

(34)

$\Delta z=-L^{-1} Z \nabla g(x)^{T} \Delta x-L^{-1}\left(Z L_{z o}+L_{10}^{\mu}\right)$

$\Delta w=-U^{-1} W \nabla g(x)^{T} \Delta x-L^{-1}\left(W L_{w o}+\right.$ $\left.L_{u 0}^{\mu}\right)$

Step $_{p}=0.9995\left\{\left(\frac{-l}{\Delta l}: \Delta l<0 ; \frac{-u}{\Delta u}: \Delta u<\right.\right.$

$0), 1\}$

Step $_{d}=0.9995\left\{\left(\frac{-z}{\Delta z}: \Delta z<0 ; \frac{-w}{\Delta w}: \Delta w<\right.\right.$

$0), 1\}$

\section{UPDATE VARIABEL}

$[x l u]=[x l u]+\operatorname{Step}_{p}[\Delta x \Delta l \Delta u]$,

$[y z w]=[y z w]+\operatorname{Step}_{d}[\Delta y \Delta z \Delta w]$ 


\section{PEMODELAN VEKTOR}

Pada metode interior point terdapat penurunan terhadap fungsi persamaan kendala dan fungsi pertidaksamaan kendala.Penurunan dilakukan terhadap tegangan dalam bentuk rectangular. Untuk fungsi persamaan kendala didapatkan penurunan orde-1:

$\frac{\partial \Delta \text { S.injeksi }}{\partial e}=I^{*}+V \cdot Y^{*}$

$\frac{\partial \Delta \text { S.injeksi }}{\partial f}=j I^{*}-j V \cdot Y^{*}$

Untuk persamaan kendala didapatkan penurunan orde- 2 :

$$
\begin{aligned}
& \frac{\partial^{2} \Delta \text { S.injeksi }}{\partial^{2} e}=\left(\text { diag }_{y p} *(-G)+(-G) *\right. \\
& \left.\operatorname{diag}_{y p}+\left(4 * \operatorname{diag}_{G} * \operatorname{diag}_{y p}\right)\right)+ \\
& \left(\operatorname{diag}_{y q} *(-B)+(-B) * \operatorname{diag}_{y q}+(4 *\right. \\
& \left.\left.\operatorname{diag}_{B} * \operatorname{diag}_{y q}\right)\right)
\end{aligned}
$$

$$
\begin{aligned}
& \frac{\partial^{2} \Delta \text { S.injeksi }}{\partial^{2} e f}=\left(\operatorname{diag}_{y p} *(B)-(B) *\right. \\
& \left.\operatorname{diag}_{y p}\right)+\left(\operatorname{diag}_{y q} *(G)-(G) * \operatorname{diag}_{y q}\right)
\end{aligned}
$$

$$
\begin{gathered}
\frac{\partial^{2} \Delta \text { S. injeksi }}{\partial^{2} f e}=\left(\frac{\partial^{2} \Delta S . \text { injeksi }}{\partial^{2} e f}\right)^{T} \\
\frac{\partial^{2} \Delta \text { S.injeksi }}{\partial^{2} f}=\frac{\partial^{2} \Delta \text { S.injeksi }}{\partial^{2} e}
\end{gathered}
$$

Untuk kendala aliran daya saluran mempunyai format vektor:

$$
\begin{aligned}
& I_{\text {flow }}^{*}=\underline{V}^{*} Y^{*}-Y^{*} \underline{V}^{*} \\
& I_{s h}^{*}=\underline{V}^{*} Y_{s h}^{*} \\
& S_{\text {flow }}=\underline{V} \cdot\left(I_{\text {fl }}^{*}+I_{s h}^{*}\right)
\end{aligned}
$$

Dalam format vektor, kendala Sij dan Sji di representasikan dalam bentuk Sflow. Turunan orde-1 dari bentuk Sflow adalah: $\frac{\partial \text { flow }^{2}}{\partial e}=2 x$ sflow $x\left((V Y)^{*}-(Y V)^{*}+\right.$ $\left.\left(V Y_{s h}\right)^{*}+V Y_{s h}^{*}\right)$

$$
\frac{\partial S f l o w^{2}}{\partial f}=2 \times \text { sflow } x\left((j V Y)^{*}-\left(j Y^{*} V\right)\right)
$$

Turunan orde-2 dari Sflow terhadap tegangan rectangular didapatkan:

$$
\begin{aligned}
& \frac{\partial S \text { flow }^{2}}{\partial e e}=2 x\left((V Y)^{*} x \frac{\partial S f l o w}{\partial e}-\right. \\
& \left(Y^{*} V\right) x \frac{\partial S \text { flow }}{\partial e}+\left(V Y_{\text {sh }}\right)^{*} x \frac{\partial S \text { flow }}{\partial e}+ \\
& \left.V Y_{\text {Sh }}{ }^{*} x \frac{\partial \text { Sflow }}{\partial e}\right) \\
& \frac{\partial S \text { flow }^{2}}{\partial e f}=2 x\left((V Y)^{*} x \frac{\partial S f l o w}{\partial f}-\right. \\
& \left(Y^{*} V\right) x \frac{\partial S f l o w}{\partial f}+\left(V Y_{s h}\right)^{*} x \frac{\partial S \text { flow }}{\partial f}+ \\
& \left.V Y_{\text {sh }}{ }^{*} x \frac{\partial \text { Sflow }}{\partial f}\right) \\
& \left(j Y^{*} V\right) x \frac{\partial S \text { flow }}{\partial f}
\end{aligned}
$$

\section{HASIL DAN PEMBAHASAN}

Ada beberapa skenario yang dilakukan oleh penulis dalam jurnal ini yaitu membandingkan metode interior point dengan aliran daya biasa yang data peningkatan beban di sistem, tegangan dan daya generator dari metode interior point akan dimasukkan kedalam data aliran daya biasa, hal ini dimaksudkan agar dapat mengkomparasikan hasil dari metode interior point dengan aliran daya biasa. Skenario yang dilakukan selanjutnya adalah melakukan skenario daya pembangkitan di sistem untuk melihat apakah metode interior point dapat merepresentasikan peningkatan beban dengan pola pembangkitan berbeda dari sistem yang sama. Berikut merupakan hasil yang diperoleh dari pembangkitan yaitu: 

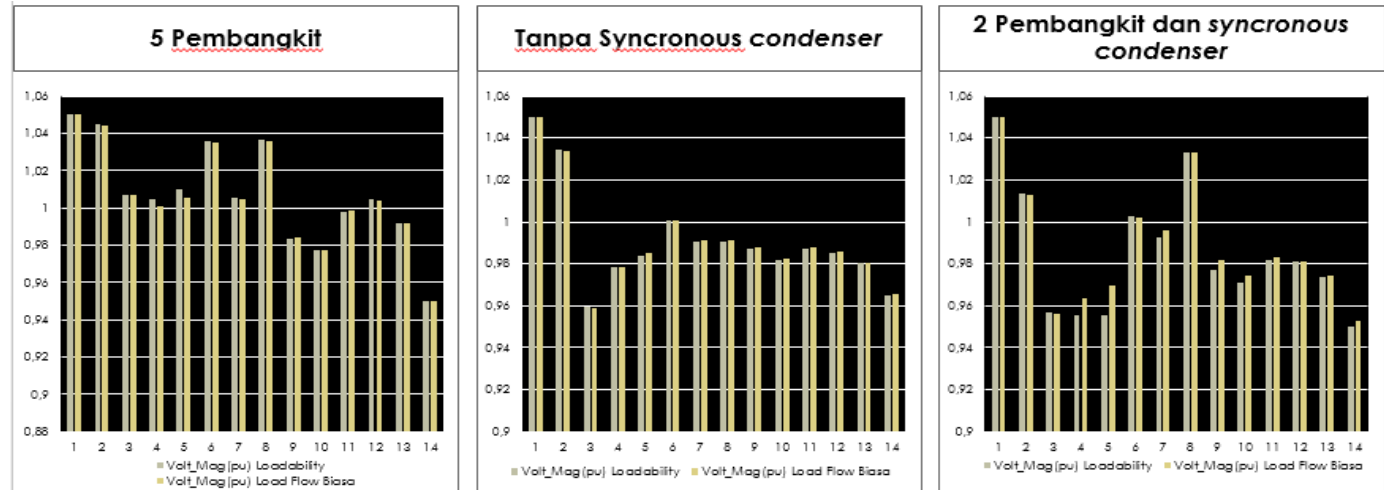

Gambar 1. Perbandingan tegangan pada metode interior point dengan aliran daya biasa IEEE 14 BUS Hasil yang diperoleh dari komparasi metode tegangan minimum melebihi dari batas yang interior point dengan aliran daya biasa ditentukan itu dikarenakan synchronous didapatkan nilai tegangan yang hampir sama, condenser yang menyuplai daya reaktif di sistem dan pada tegangan dengan 5 pembangkit dan 2 saat dilakukan skenario ini, pada sistem pembangkit dengan synchronous condenser memiliki daya reaktif yang kurang untuk memiliki tegangan maksimum di batas 1.05 dan menjaga tegangan stabil di batas minimum yang tegangan minimum pada batas 0.95 . Namun telah disetting.

pada tanpa synchronous condenser memiliki
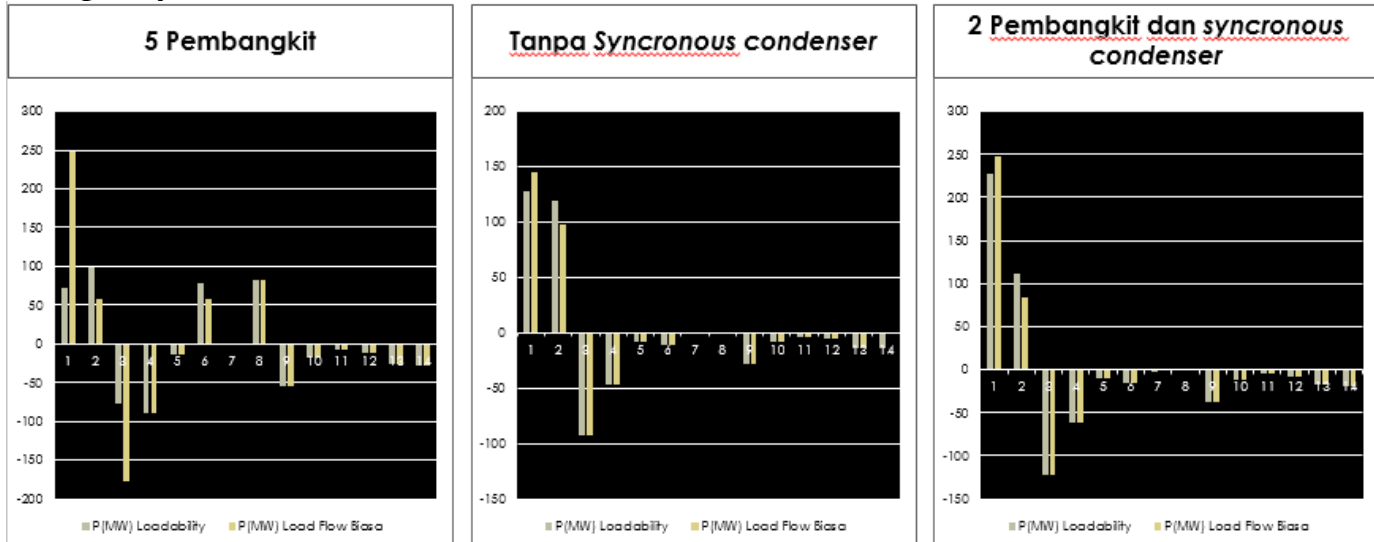

Gambar 2. Perbandingan daya aktif pada metode interior point dengan aliran daya biasa IEEE 14 BUS

Hasil yang diperoleh dari komparasi metode interior point dengan aliran daya biasa didapatkan nilai daya aktif generator yang berbeda. Daya aktif generator untuk metode interior point melakukan pembangkitan secara tersebar sedangkan pada aliran daya biasa melakukan pembangkitan terbesar di bus slack. Dengan 5 generator didapat peningkatan beban sebesar 1.873 kali dari daya beban awal disistem. Daya yang dihasilkan dari generator sebesar 332,828 MW dan daya beban sebesar 323,570 MW. Dengan tanpa synchronous condenser didapatkan peningkatan sebesar 0.977 kali dari daya beban awal sistem.Hal ini diperoleh karena berkurangnya supply daya aktif generator karena hanya melakukan 2 pembangkitan saja, daya generator sebesar 246.278 MW dan daya beban sebesar 232.035 MW. Pada pembangkitan 2 generator dan 3 synchronous condenser didaptkan nilai lambda sebesar 1.3 kali beban awal sistem, dengan daya aktif sebesar 338.453 MW dan daya beban sebesar 309.204 MW. 

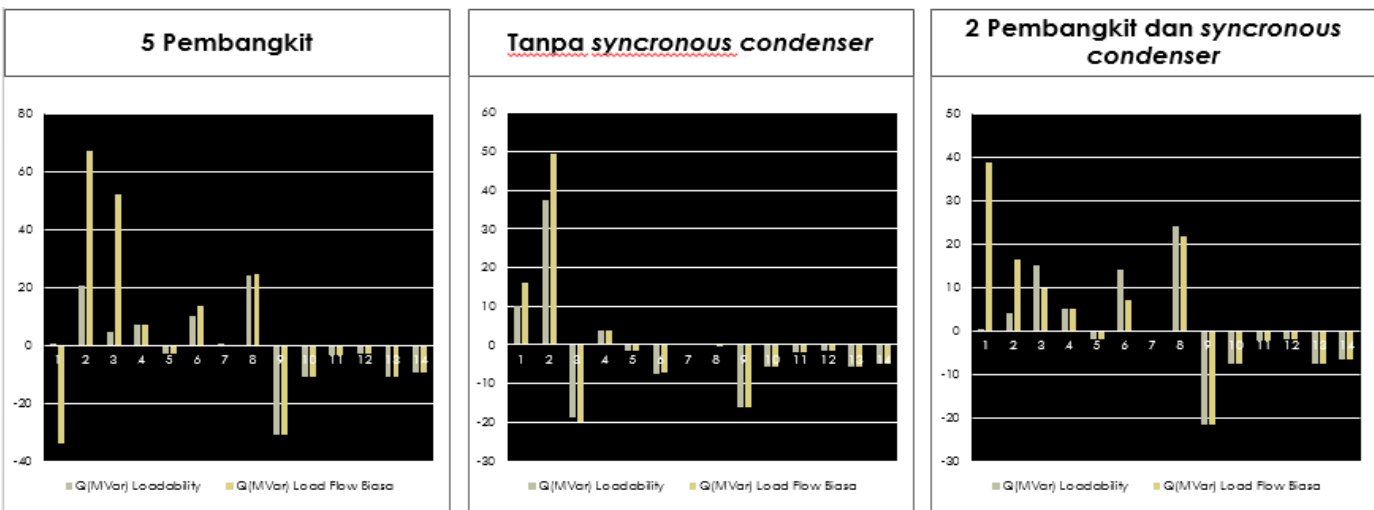

Gambar 3. Perbandingan Daya reaktif pada metode interior point dengan aliran daya biasa IEEE 14 BUS

Hasil yang diperoleh dari komparasi metode interior point dengan aliran daya biasa didapatkan nilai daya reaktif generator yang berbeda. Daya reaktif generator untuk metode interior point melakukan pembangkitan dibatas range yang ditentukan sedangkan pada aliran daya biasa menyerap daya reaktif di bus generator.
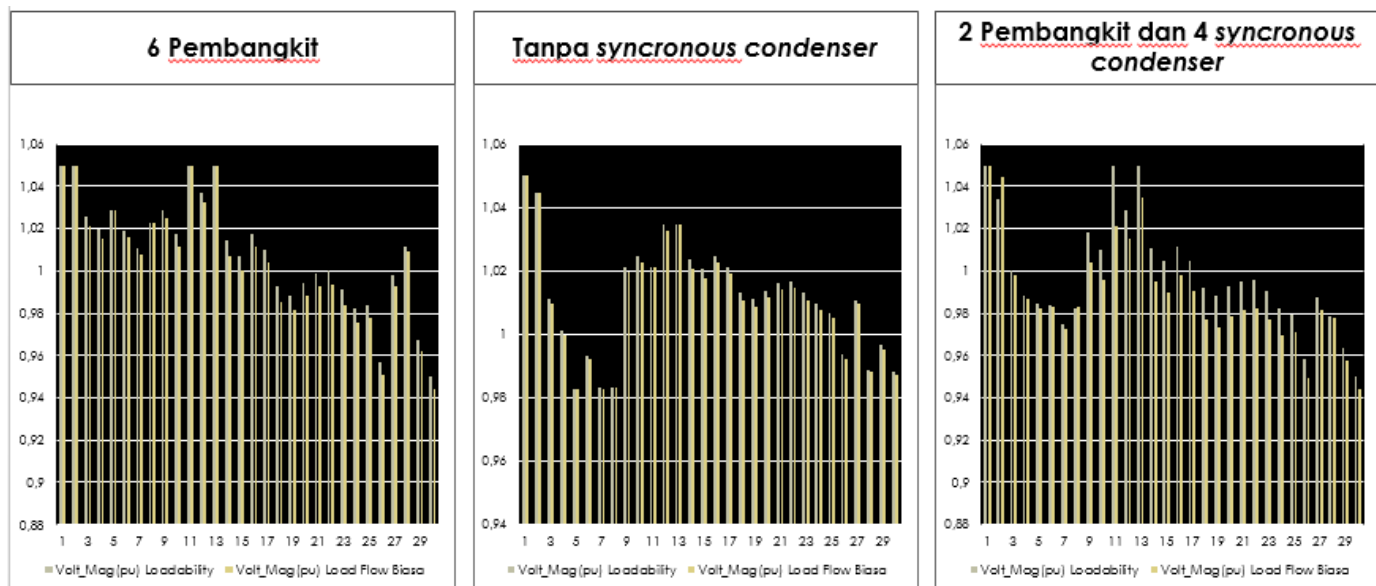

Gambar 4. Perbandingan tegangan pada metode interior point dengan aliran daya biasa IEEE 30 BUS

Hasil yang diperoleh dari komparasi metode interior point dengan aliran daya biasa didapatkan nilai tegangan yang hampir sama, namun pada aliran daya biasa untuk nilai tegangan minimum diatas 0.95 namun pada metode interior point nilai tegangan minimum berada pada batas 0.95 .
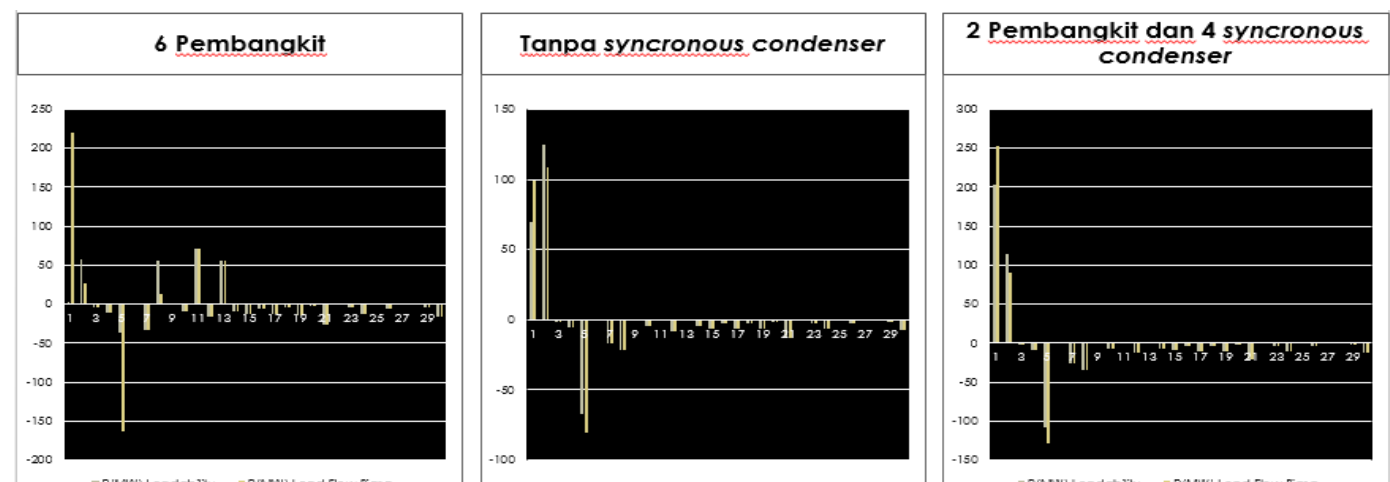

Gambar5. Perbandingan daya aktif pada metode interior point dengan aliran daya biasa IEEE 30 BUS 
Metode interior point pada persamaan ini memperlihatkan pembangkitan daya aktif dilakukan secara tersebar dan aliran daya biasa dilakukan dengan supply terbesar berada pada bus slack.Untuk 6 pembangkitan di generator didapatkan peningkatan beban sebesar 1.458 kali dari daya beban awal, pada skenario tanpa synchronous condenser didapatkan peningkatan beban sebesar 0.717 kali, dan pada 2 pembangkitan dan 4 synchronous condenser didapatkan peningkatan beban sebesar 1.145 kali beban awal sistem.
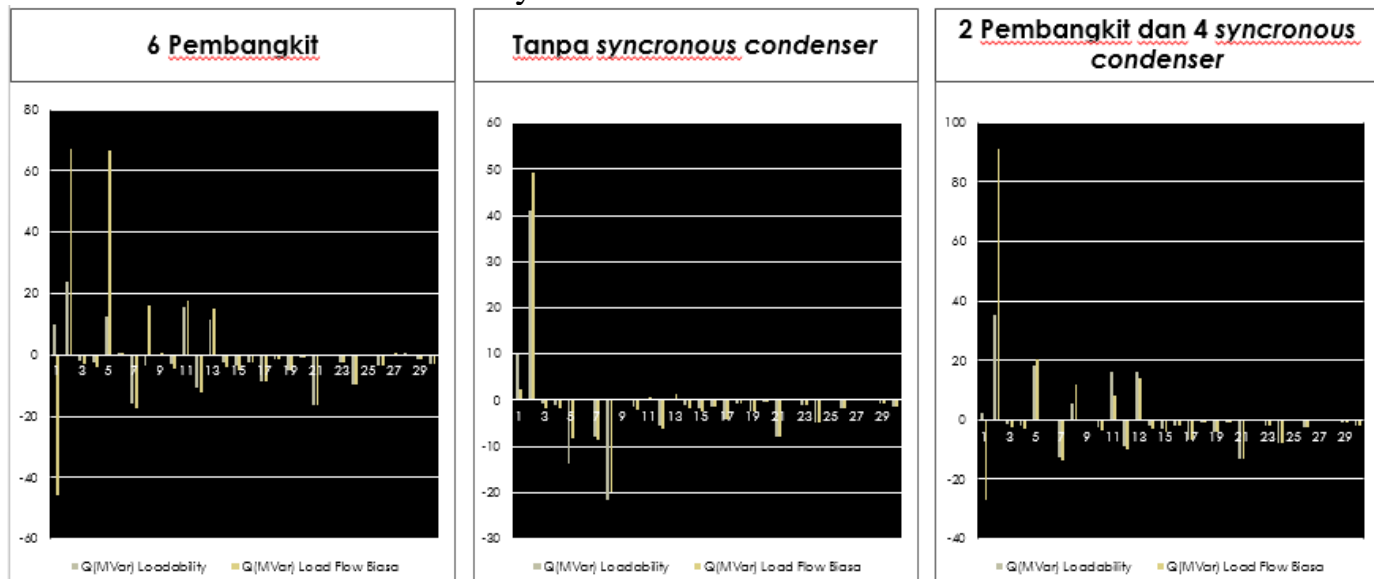

Gambar 6. Perbandingan Daya reaktif pada metode interior point dengan aliran daya biasa IEEE 30 BUS

Hasil yang diperoleh dari komparasi metode interior point dengan aliran daya biasa didapatkan nilai daya reaktif generator yang berbeda. Daya reaktif generator untuk metode interior point melakukan pembangkitan dibatas range yang ditentukan sedangkan pada aliran daya biasa menyerap daya reaktif di bus generator.

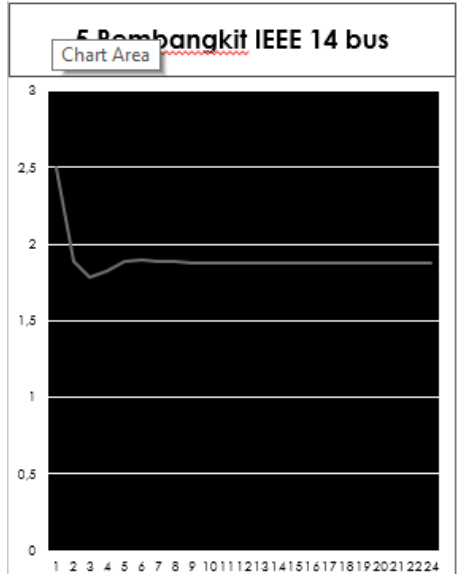

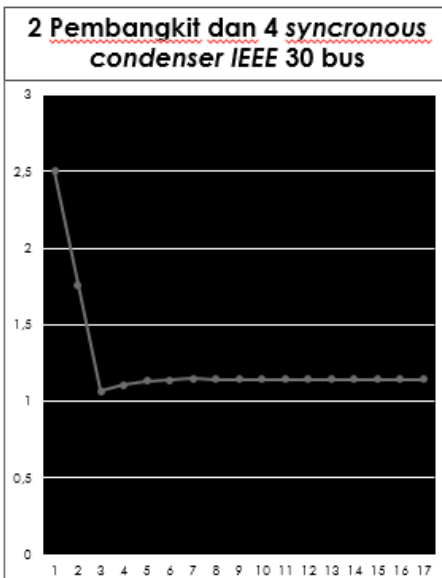

Gambar 7. Lambda tiap iterasi

Pada beberapa skenario yang dilakukan, diambil beberapa data untuk peningkatan beban yang dilakukan saat proses perhitungan tiap iterasi didapatkan bahwa ketika dimulai dari nilai tengah saat inisialisasi, pada iterasi berikutnya terjadi penyesuaian terhadap pola pembebanan yang dilakukan hingga mencapai pada titik pembebanan tersebut dikatakan maksimum. 

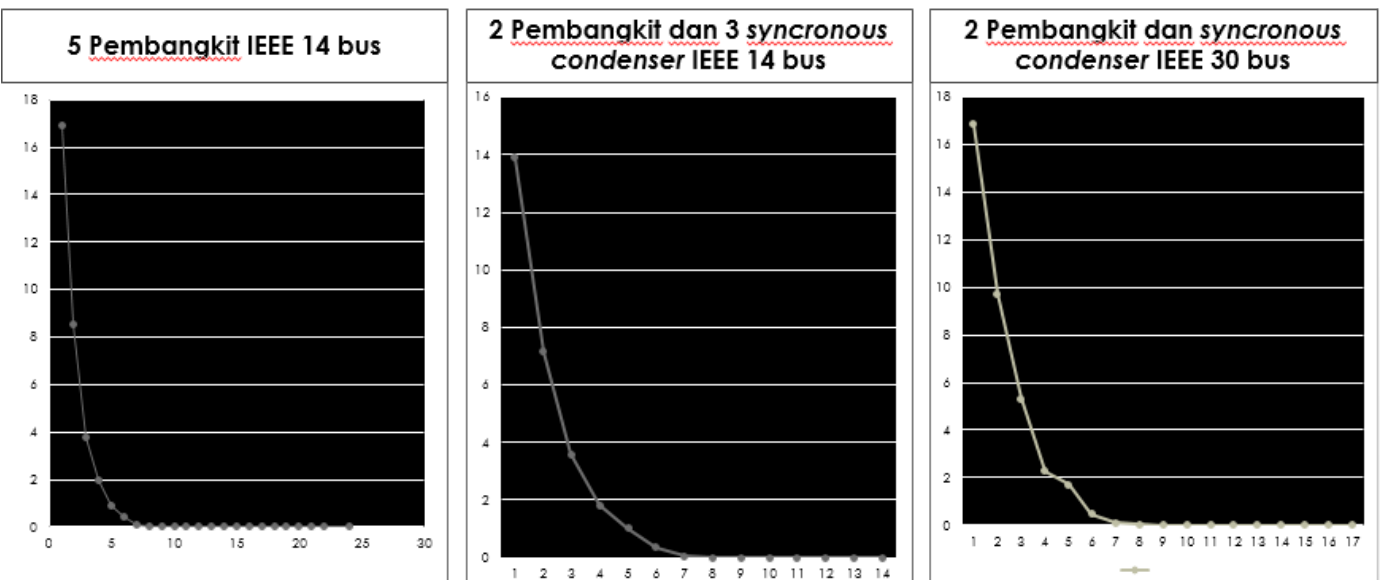

Gambar 8 . Complementary gap
Nilai Complementary gap pada metode interior point merupakan hal yang perlu dipertimbangkan. Nilai ini berhubungan dengan arah titik optimasi yang paling optimal dari suatu persamaan. Complementary gap merupakan selisih jarak variabel bawah dengan variabel atas dari suatu persamaan yang dioptimisasi. Jika pada analisis aliran daya mempertimbangkan nilai missmatch yang konvergen, maka saat

\section{KESIMPULAN}

Adapun kesimpulan yang didapatkan pada jurnal ini mengenai penerapan metode interior point untuk studi pembebanan maksimum ini adalah:

1. Melalui skenario pembangkitan yang dilakukan, menunjukkan bahwa metode interior point dapat merepresentasikan pembebanan maksimum dengan skenario pembangkitan berbeda mendapatkan hasil peningkatan beban yang berbeda juga.

2. Metode interior point dikomparasikan dengan aliran daya biasa yang daya generator, daya beban, tegangan diinputkan sesuai data hasil metode interior point memperlihatkan bahwa dengan metode aliran daya biasa menghasilkan daya yang tidak sesuai dengan batasan fungsi kendala yang dilakukan, sedangkan pada metode interior point tidak melanggar batas fungsi kendala yang ada. menggunakan metode interior point, selain nilai missmatch, nilai konvergen complementary gap menjadi parameter penting dalam pengoptimasian suatu persamaan kendala. Terlihat hasil complementary gap pada gambar 8 nilai complementary gap sudah konvergen pada iterasi 7 namun karena syarat missmatch konvergen belum terpenuhi sehingga tetap dilakukan perhitungan.

\section{Daftar Pustaka}

[1] H. Saadat, Power System Analysis, New York: Mc Graw-Hill Book Company, 1999.

[2] L. Hakim, Development of a Power Flow Software for Distribution System Analysis Based on Rectangular Voltage Using Python Software Package, Yogyakakrta: dalam 6th International Conference on Information Technology and Electrical Engineering (ICITEE), 2014.

[3] B. F. W. Allen J. Wood, Power Generation Operation and Control, United States of America: A Wiley Interscience Publication, 1996.

[4] L. Hakim, "Vectorized Power Flow in Full Rectangular Coordinates Using Newton Rhapson Method," pp. 1-4, 2016.

[5] Y. S. M. I. Xi-Fan Wang, Modern Power System Analysis, Republic of China: Spinger, 2008.

[6] R. I. H. S. Junji Kubokawa, "A Solution of Optimal Power Flow with Voltage 
Stability Constraints," IEEE, p. 625, 2000.

[7] T. Gonen, Modern Power System Analysis, New York: GRC Press, 2013.

[8] H. S. J. K. Hua Wei, "An Interior Point Nonlinear Programming for Optimal Power Flow Problems with A Novel Data Structure," IEEE, p. 870, 1998.

[9] Q. Z. W. h. Yang Yude, "Power Flow Calculation Based on Non-linear Programming Model and Vectorization Mode," IEEE, p. 1729, 2007.

[10] A. W. Satriawan, ANALISA PERFOMANSI METODE VECTORIZED ALGORITHM, Bandar Lampung: Universitas Lampung, 2017.

[11] Y. Y. Zhijun Qin, "Vectorization Implementation of Optimal Power Flow in Rectangular Form Based on Interior," IEEE, 2008.

[12] L. H. ANNISA ZAUHAR NAFISAH, "Optimasi Pelepasan Beban Dengan Metode Linear," UNILA, 2017.

[13] R. P. O. A. C. Mary B. Cain, "History of Optimal Power Flow and Formulations," 2012.

[14] X. J. S. G.D.Irisarri, "Maximum Loadability of Power System usinhg Interior Point Non- Linear Optimization Method," IEEE, vol. 12, 1997. 